\section{Foam Glass Ceramics as Composite Granulated Heat-Insulating Material}

Afanasy S. APKARYAN - Tomsk State University of Control Systems and Radioelectronics, Tomsk (Russia) - Institute of Strength Physics and Materials Science SB RAS, Tomsk (Russia) • asaktc@ispms.tsc.ru

Sergey N. KULKOV - Tomsk State University (TSU), Tomsk (Russia) Institute of Strength Physics and Materials Science SB RAS, Tomsk (Russia) - kulkov@ms.tsc.ru LÁsZLó A. GÖMZE - University of Miskolc, Egyetemváros, Miskolc (Hungary) IGREX Engineering Service Ltd, Igrici (Hungary) - femgomze@uni-miskolc.hu - igrex2009@yandex.ru Received: 28. 06. 2014. - Érkezett: 2014. 06. 28. - http://dx.doi.org/10.14382/epitoanyag-jsbcm.2014.8

\section{Abstract}

Manufacturing technology for granulated glass-ceramic heat-insulating material made from crushed glass, clay and organic additives was developed. The effect of the basic physical characteristics of the components of the charge on the process of pore formation is studied. According to the research results, the basic parameters affecting the sustainability of the swelling glass are specified. A rational charge composition, thermal and gas synthesis mode are chosen such that the partial pressure of gases is lower than the surface tension of the melt. This enables the formation of granules with small closed pores and a vitrified surface. The regularities of the effect of composition and the firing temperature on the properties of the granules are determined. The resulting granulated heat-insulating material is produced with a bulk density of $260-280 \mathrm{~kg} / \mathrm{m}^{3}$, and pellet strength of $1.74 \mathrm{MPa}$, thermal conductivity of $0.075 \mathrm{~W} / \mathrm{m}{ }^{\circ} \mathrm{C}$, and water absorption of $2.6 \%$ by weight. The results are given of the study of the dependence of the thermal conductivity coefficient and mechanical strength of the granules on the bulk density. Keywords: Carbon, clays, crushed glass, density, durability, granulate, glass-ceramics, heatinsulation, sawdust, thermal conductivity, water absorption.

\section{Introduction}

The advantage of foam glass compared to other well-known insulating materials is its unique combination of insulating and functional characteristics $[1,2]$, which enables the use of this material in various industrial spheres $[3,4]$ including heat insulation lightweight aggregate concretes as well $[5,6,7]$.

The aim of this research is the experimental and theoretical justification of the feasibility of producing a competitive environmentally friendly insulation - granulated foam glass ceramic, which would provide effective thermal and physical characteristics for the construction industry and thermal engineering. For achieving this goal, the following tasks were set:

a. Experimentally validate an increase in the functional, thermal and physical characteristics of foam glass ceramics by means of selection and optimization of the structural phase condition of granulated material.

b. Study the physical and chemical processes of pore formation and crystallization of aluminum silicate hot melt during the formation of the phase composition and foam glass ceramic structure.
Dr. Afanasy S. Apkaryan Dr. Apkaryan has PhD in Technical Sciences. He is head of Department and responsible for Nanotechnology in the Institute of Strength Physics and Materials Science of the Russian Akademy of Science since 2005. Candidate of Technical Sciences. Specialists in the field of thermal physics and ceramic production. Associate Professor in Tomsk State University of Control Systems and Radioelectronics. Dr. Apkaryan is autor or co-autor of 2 books, 27 articles and 3 Russian patents.

Prof. Sergey N. Kulkov Prof. Kulkov is head of Department of Ceramics in the Institute of Strength Physics and Materials Science of the Russian Academy of Science since 1989. He has got scientific degrees "Doctor of Physics and Mathematical Sciences" in 1990. Since 1992 he's working as professor both in Tomsk State University and in Tomsk Polytechnic University. In 1997 he had a Soros Professor grant. His research works are represented in 5 books, more than 150 articles, 18 patents and many International Symposiums and Conferences. At present he is head of department "Theory of Strength and Mechanic of Solids”, member of „The American Ceramic Society” of „The APMI - International” and the DYM AT Society (France)

Prof. László A. Gömze Establisher (in July 1st, 1999) and head of Department of Ceramics and Silicate Engineering in the University of Miskolc, Hungary. Since then 7 students from the department have successfully completed their PhD theses and 4 of them were managed by Prof. Gömze. He is author or co-author of 2 patents, 5 books and more than 250 scientific papers. Recently, he is the chair of the International Organization Board of ic-cmtp ${ }^{3}$ the $3^{\text {rd }}$ International Conference on Competitive Materials and Technological Processes (2014) and ic-rmm ${ }^{2}$ the $2^{\text {nd }}$ International Conference on Rheology and Modeling of Materials (2015).

\section{Materials and experiments}

Crushed glass, clay, carbon and sawdust were used as the material for the production of granulated foam glass ceramic. In order to increase the mechanical strength of interpore partitions and the surface of granules and, consequently, the granule mechanical strength in general, clay was added to the composition, and as it decreased the hot melt viscosity, an organic additive - sawdust - was used to enable stable foaming with a gassing agent. Glass types with high foam glass production characteristics include: $\mathrm{SiO}_{2}-60 \ldots 72,5 \%, \mathrm{Fe}_{2} \mathrm{O}_{3}-0 . .2,5 \%, \mathrm{CaO}-4 \ldots 6,0 \%, \mathrm{MgO}-$ $1,5 \ldots 2,5 \%, \mathrm{Na}_{2} \mathrm{O}-12,5 \ldots 15,0 \%, \mathrm{Al}_{2} \mathrm{O}_{3}-1,2 \ldots 1,57$ [8].

\subsection{Glass}

Three types of glass (Table 1) were used in the experiments. The first type of the crushed glass was float (window) glass.

\begin{tabular}{|c|c|c|c|c|c|c|c|c|c|c|c|}
\hline \multirow[b]{2}{*}{ Type of glass } & \multicolumn{11}{|c|}{ Glass chemical composition, \% } \\
\hline & $\mathrm{SiO}_{2}$ & $\mathrm{Al}_{2} \mathrm{O}_{3}$ & $\mathrm{Fe}_{2} \mathrm{O}_{3}$ & $\mathrm{CaO}$ & $\mathrm{MgO}$ & $\mathrm{R}_{2} \mathrm{O}$ & $\mathrm{SO}_{3}$ & $\mathrm{~K}_{2} \mathrm{O}$ & $\mathrm{Na}_{2} \mathrm{O}$ & $\mathrm{Cr}_{2} \mathrm{O}_{3}$ & $\mathrm{BaO}$ \\
\hline Window glass & 73.0 & 0.9 & 0.12 & 8.7 & 3.6 & 13.6 & 0.53 & - & - & - & - \\
\hline Bottle glass & 70.7 & 4.0 & 0.65 & 6.5 & 3.5 & - & - & - & 14.5 & 0.15 & - \\
\hline Lamp glass SL96-1 & 71.9 & 1.5 & 0.1 & 5.5 & 3.5 & - & - & 0.15 & 16.1 & - & 2.0 \\
\hline
\end{tabular}

Table 1. Chemical composition of the used crushed glass types

1. táblázat A vizsgálatokhoz használt üvegcserép kémiai összetétele 
Chemical composition of windowpanes is the closest to this. Their distinctive characteristic is a low level of $\mathrm{Al}_{2} \mathrm{O}_{3}$ compared to other types of glass.

The second important source of crushed glass was green bottle glass. This type of glass has a high level of $\mathrm{Fe}_{2} \mathrm{O}_{3}-0.65 \%$, $\mathrm{Al}_{2} \mathrm{O}_{3}-4.0 \%, \mathrm{Na}_{2} \mathrm{O}-14.5 \%$, which is an important factor for the process of foaming.

The third source of crushed glass was electric bulb glass SL96-1 from the Tomsk Electric-Bulb Factory with chemical composition described in Table 1.

During the production of granulated foam glass ceramics it is necessary to carry out the correction of the functional composition of a charge taking into account every type of glass used.

\subsection{Clay}

A range of clay deposits was studied in order to determine the local raw material base for the production of foam glass ceramics [9].

The best results were obtained using clay that is classified as pulverous loam, with a domination of $\mathrm{SiO}_{2}-70.73 \%$; $\mathrm{Al}_{2} \mathrm{O}_{3}-$ $17.12 \%$ and $\mathrm{Fe}_{2} \mathrm{O}_{3}-5.68 \%$ in its chemical composition. The presence of this type of clay in the charge leads to a decrease of water consumption to $3-4 \%$, increasing the mechanical durability and fire resistance of the granules of foam glass ceramics (Table 2).

\begin{tabular}{lcc} 
Type of particles & Size of particles, $\mathrm{mm}$ & Particle content, \% \\
\hline Clay & $<0.005$ & $20 \ldots 32$ \\
\hline Silt & $0.005 \ldots 0.05$ & $68 \ldots 80$ \\
\hline Sand & $0.05 \ldots 1.0$ & absent
\end{tabular}

Table 2. Granulometric characteristics of particles

2. táblázat Az 5-10 mm szemcseátméröjü duzzasztott agyag (Keramzit) és a $260 \mathrm{~kg} / \mathrm{m}^{3}$ térfogat-sürüségü kompozit üvegkerámia-hab legfontosabb tulajdonságainak összehasonlitása

\subsection{Organic additive}

In contrast to traditional foam glass compositions, the distinctive characteristic of the charge composition proposed for the production of foam glass ceramics was using sawdust as an organic element of the charge.

Softwoods and hardwoods contain pentosans (a type of hemicellulose) that hydrolyze in the presence of water and turn into simple sugars that are soluble easily in water. Simple sugars prevent good adhesion of the charge particles with sawdust. Therefore, preference was given to softwoods as they contain 2-3 times more pentosans than hardwoods.

The balance of chemical agents in sawdust was about $50 \%$ carbon, $6.0 \%$ hydrogen, $44 \%$ oxygen and approximately $1.0 \%$ nitrogen.

\subsection{Gassing agent}

When justifying the choice of gassing agent, the conjunction of temperature intervals of hot melt appearance with required viscosity and formation of the peak partial pressure of gaseous products in organic burn off were taken into account. Carbon was used as the gassing agent.
In the course of the study the following charge composition was used ( $\%$ by weight): crushed glass 67 - 84; clay 8 - 25; carbon 5 and sawdust -3 . The charge degree of fineness was $0.45-0.15 \mathrm{~mm}$.

The granules were made in the following way: glass cullet was further crushed in a grinder to $1.5-3.0 \mathrm{~mm}$, and then in a ball mill combined with sawdust to the particle specific surface area of $300-350 \mathrm{~m}^{2} / \mathrm{kg}$. In such a way the sawdust was added to the charge during the moment of glass grinding, which enabled their pulverizing to a wood powder with an obtainment of a high shape factor of wood fiber (length-to-thickness ratio) equal to 4 and the size of particles no more than 560 microns. Grinding process of carbon and clay was also performed in the ball mill.

The obtained glass-wool and carbon-clay powders were dosed and loaded in a rod vibrating mill where they were jointly mechanically activated to a specific surface area of $400 \mathrm{~m}^{2} / \mathrm{kg}$. The obtained charge was gaged with water (10-15\% of the charge mass) for gaining the required plasticity, and then was formed into granules of 3-8 $\mathrm{mm}$ in size.

The experiments were carried out with a permanent carbon value of $5 \%$ and organic additives (sawdust) of $3 \%$, as it was described above.

\section{Results and discussions}

Granule burning was carried out at a temperature of 830 $850{ }^{\circ} \mathrm{C}$ within a sintering range of foaming mixtures equal to $4-6$ minutes. When the charge contains $8 \%$ of clay there commences a formation of granules consisting of cells ranging from 0.135 to $2.7 \mathrm{~mm}$ in size, and occasionally connected with communicated channels (Fig. 1) and with an interpore partition thickness of $0.07-0.1$ micrones. The granule density was $200 \mathrm{~kg} / \mathrm{m}^{3}$.
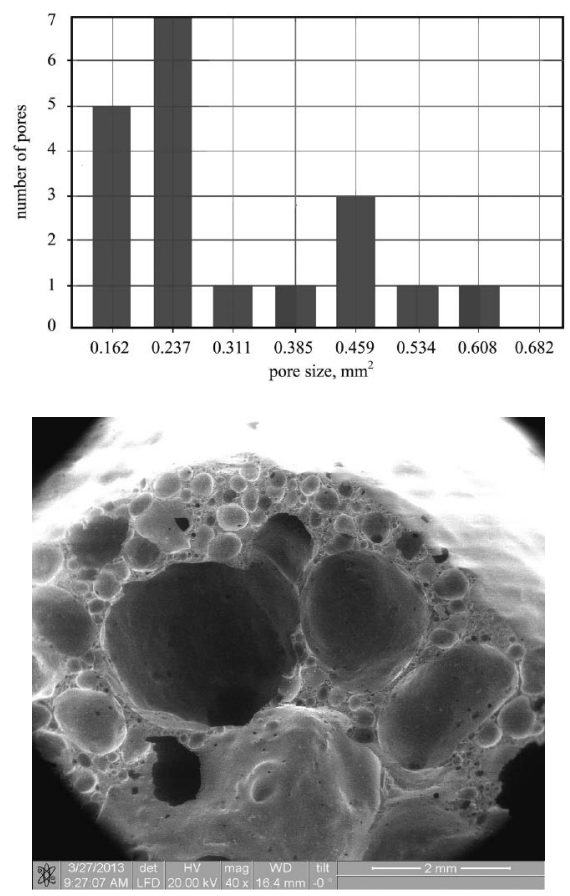

Fig. 1. Histogram of pore dispersion in quantity and size and pore structure of foam glass ceramics with $8 \%$ clay containment in the charge. Granule density is $200 \mathrm{~kg} / \mathrm{m}^{3}$

1. ábra $8 \%$ agyagot tartalmazó duzzasztott üvegkerámia-hab granulátum pórus szerkezetének hisztogramja. A granulátum sürüsége $200 \mathrm{~kg} / \mathrm{m}^{3}$ 
The formation and steadiness of the foam depends on the surface energy at the boundary between gas and liquid. When adding $10 \%$ of clay to the charge, the surface tension and free energy of the system, which forms fragile foam, start to increase. As the proportion of clay starts to increase beyond $25 \%$, the boundary surface between phases starts to decrease; the pores and the gas emission mutually combine, and the foam settles.

In order to overcome this challenge the decision was made to use sawdust as an organic additive in the charge. It was estimated experimentally that adding up to $3 \%$ of sawdust with a simultaneous increase of the foaming temperature up to $830{ }^{\circ} \mathrm{C}$ and the time of pore formation up to 5 minutes, the amount of gases and their partial pressure would increase. Furthermore, the viscosity of the hot melt begins to decrease and the particle sintering commences, leading to the formation of glass ceramic mass.

When increasing the temperature by $70-110{ }^{\circ} \mathrm{C}$ higher than the glass softening point, sodium sulphate reacts with coke carbon and the carbon of burning organic additives (sawdust) with the formation of carbon monoxide:

$\mathrm{Na}_{2} \mathrm{SO}_{4}+4 \mathrm{C}=\mathrm{Na}_{2} \mathrm{~S}+4 \mathrm{CO}$

The presence of clay facilitates an increase of the glass softening point and the bloating phase, and containment up to $5.0 \%$ of carbon and up to $3 \%$ of sawdust enables the formation of a rather large amount of gas with high partial pressure. The charge composition is made in such a way that the gas partial pressure is lower than the surface tension of a hot melt, which enables an increase in the dividing surface between phases and equal distribution of pores in a hot melt.

In the process of foaming, the pores mutually combine at a low rate. The gases in the pores work against the energy caused by surface tension. The presence of clay in a hot melt significantly increases the energy of the surface tension, and the gas pressure in pores decreases as the pores diminish. As a result there are up to $92 \%$ of closed pores of $0.2-0.4 \mathrm{~mm}$ in size, with a thickness of the dividing partition within the bounds of 0.07-0.1 micron up to 12 microns.

According to the silicate foam formation mechanism, a maximum of closed cells is formed under the foaming of homogeneous systems with an optimal viscosity of hot melts, in which smooth foaming, and, at the same time, a high fixity of formed foam caused by its structural-mechanical factor are provided (Fig. 2). The granule density is $260 \mathrm{~kg} / \mathrm{m}^{3}$.

Mutual combination and formation of open pores occurs in the initial foaming period - the period of free gas exit. This process stops as the gas pressure in the system equalizes. Under a relatively high hot melt viscosity, the equilibrium state of the system is gained much slower. The formation of closed pores in foam glass ceramics is enabled by adding fusible clay into the charge, which decreases the viscosity of a hot melt and significantly increases its plasticity, and at the same time raises the mechanical strength of pore partitions. As a result, the pore partitions are not pierced and the formation of new pores occurs independently, without the impact of gassing processes in neighboring pores.
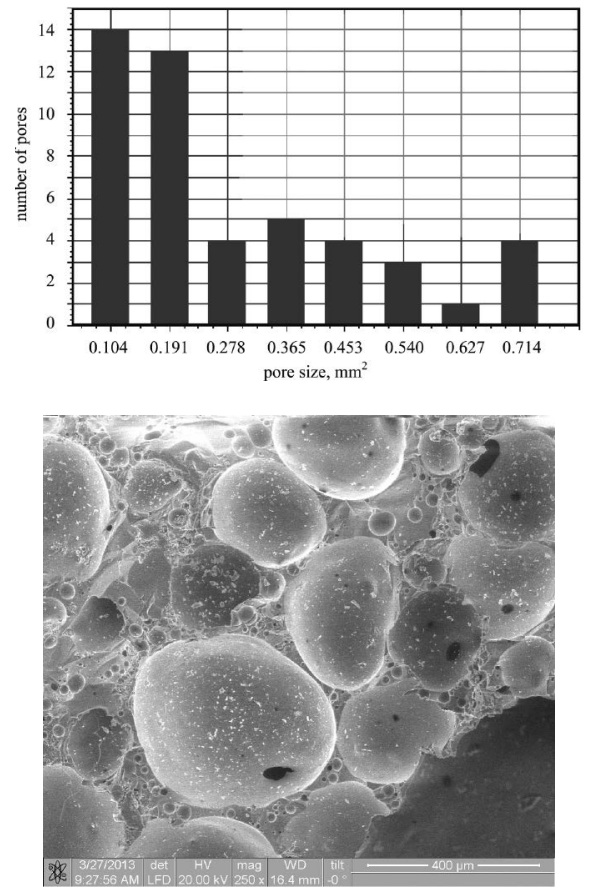

Fig. 2. Histogram of pore dispersion in quantity and size and pore structure of foam glass ceramics with $10 \%$ clay containment in the charge. Granule density is $260 \mathrm{~kg} / \mathrm{m}^{3}$

2. ábra $10 \%$ agyagot tartalmazó duzzasztott üvegkerámia-hab granulátum pórus szerkezetének hisztogramja. A granulátum sürüsége $260 \mathrm{~kg} / \mathrm{m}^{3}$
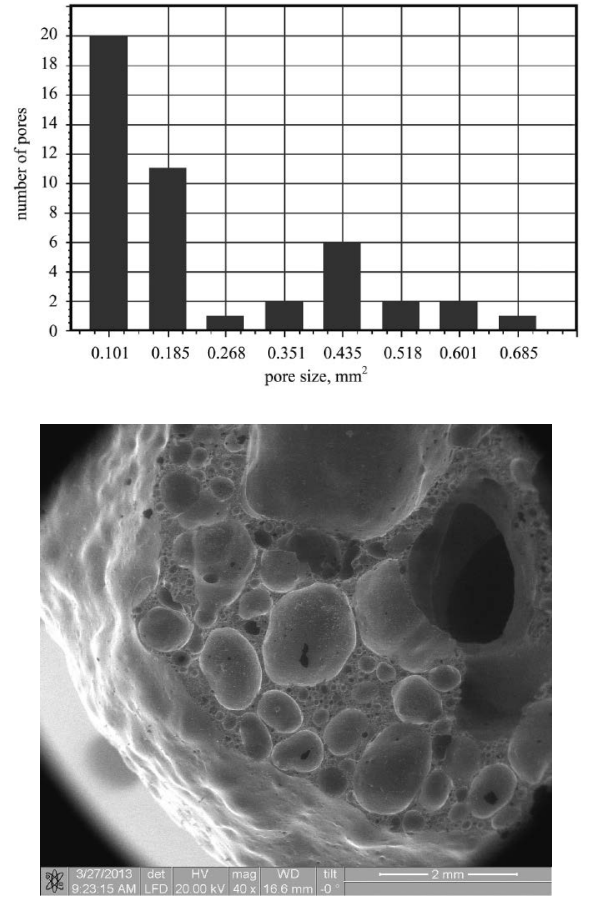

Fig. 3. Histogram of pore dispersion in quantity and size and pore structure of foam glass ceramics with $25 \%$ clay containment in the charge. The granule density is $290 \mathrm{~kg} / \mathrm{m}^{3}$

3. ábra 25\% agyagot tartalmazó duzzasztott üvegkerámia-hab granulátum pórus szerkezetének hisztogramja. A granulátum sürüsége $290 \mathrm{~kg} / \mathrm{m}^{3}$

Clay as a fusible additive in the rational composition of a charge plays the role of stabilizer. The stabilizing action of clay enables the formation of a so-called energy barrier, which increases the mechanical strength of partitions with the narrowest thickness. Increasing the clay proportion up to $25 \%$ enables the rise of 
the hot melt viscosity, and an increase in the thickness and mechanical strength of the walls. Gas pressure in pores is not enough for their size increase. As a result small pores start to appear - from 0.036 to 0.135 microns, and the thickness of pore partitions expands and varies from $0.07-0.1$ micron to 50 microns (Fig. 3). The granule density is $290 \mathrm{~kg} / \mathrm{m}^{3}$.

The glassy layer formed on the granular surface enables the formation of a solid surface at the stage of bloating, as a result of which the mechanical compressive strength is increased and the water absorption decreases.

The formation of a porous structure during heating is divided into the following stages:

- Synthesis - formation of sintered material during heating to the sintering temperature range;

- Bloating - the process of volume and structural changing of material;

- Annealing - a special mode of cooling.

As follows from the study, an optimal thermal profile for the sintering regime and granular porization was determined (Fig. 4).

A thermal shock in the zone of high temperatures $\left(830^{\circ} \mathrm{C}\right)$ in areductive conditions with $3.0 \% \mathrm{CO}$ containment is characteristic for granular thermal processing. Furthermore, the mechanical strength comes to the maximum while granules are in the high temperature zone for 5-6 minutes. Thermal cycle foaming $\rightarrow$ pore formation $\rightarrow$ annealing (Fig. 4) provides an optimal time for granules in the foaming zone, regulating the size and the quantity of pores and prevents the process of bubble coalescence (increasing of pore size), for which greater time in the high temperature zone is required.

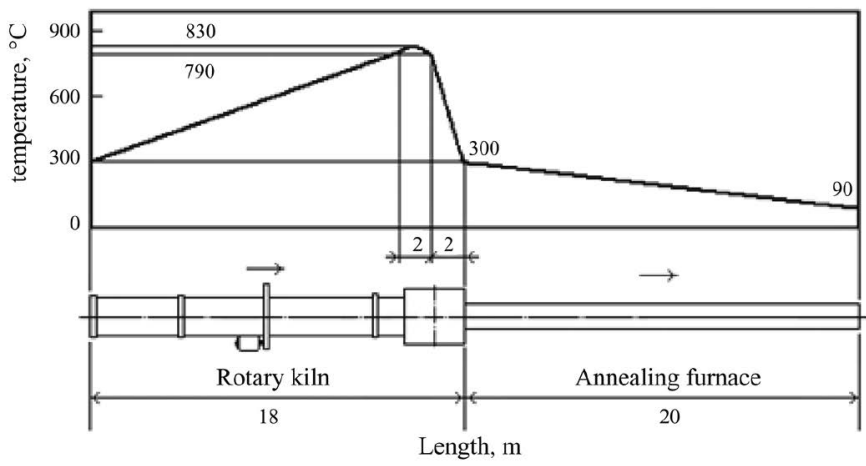

Fig. 4. Optimal scheme of thermal cycle of foam glass ceramic granule sintering and porization

4. ábra Optimális hökezelési görbe jó pórusszerkezetü üvegkerámia-hab granulátum létrehozásához

When granules stay in the high temperature zone more than 10 minutes, the probability of dissipative phenomena is increased, i.e. the extension and collapsing of pores. As the quantity of pores decreases, they start to expand by up to $2 \mathrm{~mm}$, and the partitions become fragile and thin. When foam glass ceramic is foaming, the structure of the pores being formed is mainly determined by rheological characteristics of an alumina-silicate melt. The strength of pore membrane during the extension depends upon the viscosity of the melt, which provides the solidity of partitions and the surface strength in the high temperature zone.

Annealing is necessary to fix the pore structure and to relieve temperature stresses in the pores. Experiments have shown that the best result is achieved when annealing starts at a temperature of $300{ }^{\circ} \mathrm{C}$ and ends at $90{ }^{\circ} \mathrm{C}$. The rate of the temperature decrease is 11.6 degree $/ \mathrm{min}$. Such a high rate, without granule breakage and shelling of the surface, is enabled by the presence of clay in the charge and a long period of crystallization. Clay enables the formation of fire resistant alumina-silicate matrix.

To study the dependence of the thermal conductivity coefficient on medium density and compressive strength, studies with a change of rational composition of a charge were conducted. As the studies showed (Fig. 5) all three criteria - mechanical compressive strength, density and thermal conductivity - depend on the size and the quantity of pores, and on the thickness and the composition of partitions. When density is increased the thermal conductivity and the granular mechanical strength grow by means of increasing the percentage of clay in the composition of charge. As the temperature increases, the melt viscosity decreases. Gas pressure rises and the shear action of capillary forces develops. The pores get filled with a fluid phase, which leads to a thickening of the material.

The studies of temperature-time regimes within space factors determined an optimal component proportion in the charge for obtaining the required porous structure. Moreover, small closed pores equally dispersed over the granule surface appear (Fig. 2). The granular mechanical strength is between $0.82-1.74 \mathrm{MPa}$.

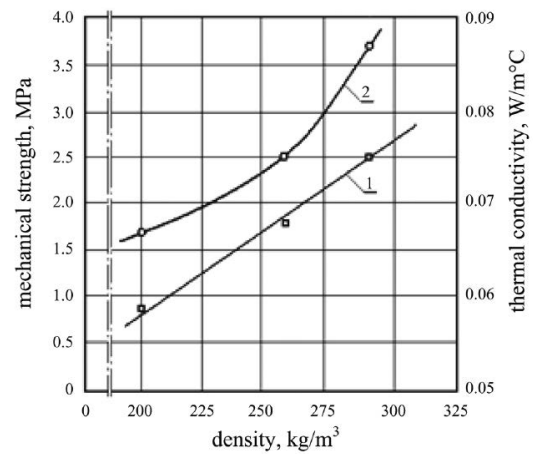

Fig. 5. Dependence of foam glass ceramic serviceability on its density 1 - Mechanical strength, $(\mathrm{MPa}) ; 2$ - thermal conductivity, $\left.\mathrm{W} / \mathrm{m} .{ }^{\circ} \mathrm{C}\right)$

5. ábra Üvegkerámia-hab granulátum legfontosabb tulajdonságainak függése a térfogatsürüségtöl

1 - Mechanikai szilárdság (MPa); 2 - Hővezetési tényezö $\left(W / m^{\circ} \mathrm{C}\right)$

Foam glass water absorption depends upon the pore characteristics: their size, quantity and structure (closed and open). Low water absorption is one of the most important factors in choosing the composition of a charge, as this parameter is inversely dependent both upon the density (Fig. 6) and thermal conductivity coefficient.

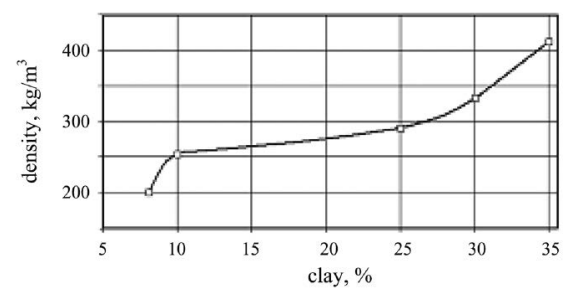

Fig. 6. The impact of clay proportion in the charge on the density of foam glass ceramics

6. ábra Üvegkerámia-hab granulátum térfogatsürüségének függése a nyersanyagkeverék agyagtartalmától 
The results of the water absorption test for foam glass ceramics are shown in Fig. 7.

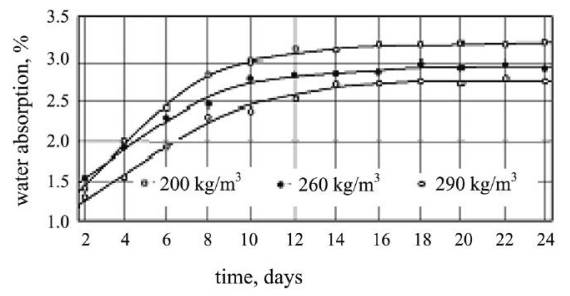

Fig. 7. The change of foam glass ceramic granule water absorption depending on the density change

7. ábra Üvegkerámia-hab granulátum vízfelvételének függése a térfogatsürüségtöl

During the tests of granular foam glass ceramics with $260 \mathrm{~kg} / \mathrm{m}^{3}$ density to determine thermal conductivity, strength, water absorption and operating temperature, physical technical characteristics were obtained, with a significant difference from expanded clay and other insulating materials of the same density (Table 3).

\begin{tabular}{|c|c|c|c|}
\hline № & Factor & $\begin{array}{l}\text { expanded } \\
\text { clay }\end{array}$ & $\begin{array}{l}\text { granular foam } \\
\text { glass ceramics }\end{array}$ \\
\hline 1 & Pour density, kg/m³ & $500-550 *$ & 260 \\
\hline 2 & Flammability & Non-flammable & Non-flammable \\
\hline 3 & Thermal conductivity, W/m. ${ }^{\circ} \mathrm{C}$ & $0.065-0.097$ & 0.075 \\
\hline 4 & Compressive strength, $\mathrm{MPa}$ & $1.7-2.5$ & 1.74 \\
\hline 5 & Water absorption, m\% & $8-20$ & $2.6 *$ \\
\hline 6 & Upper operating temperature, ${ }^{\circ} \mathrm{C}$ & Up to 600 & 620 \\
\hline \multicolumn{4}{|c|}{$\begin{array}{l}\text { * Traditional industrially manufactured expanded clay with closed porosity, with water } \\
\text { absorption of } 6-9 \% \text { by volume }\end{array}$} \\
\hline \multicolumn{4}{|c|}{$\begin{array}{l}\text { Table 3. Results of comparing granular foam glass ceramics with } 260 \mathrm{~kg} / \mathrm{m}^{3} \text { density } \\
\text { and expanded clay gravel fractions of } 5-10 \mathrm{~mm}\end{array}$} \\
\hline \multicolumn{2}{|r|}{ 3. táblázat Habosított üveg-kerámia granulát } & $\begin{array}{l}\text { um (sürüség } 260 \mathrm{~kg} / \mathrm{m} \\
\text { gkavicséval }(5-10 \mathrm{~mm}\end{array}$ & $\begin{array}{l}\left.n^{3}\right) \text { jellemzöinek } \\
\text { szemnagyság) }\end{array}$ \\
\hline
\end{tabular}

\section{Conclusion}

It has been established that the products are fragile when the clay content in the charge is lower than $8 \%$, with a low mechanical strength and large pores; if the clay content is higher than $25 \%$ then the granules are close in their physical and technical properties to expanded clay.

Granulated foam glass ceramics with a density of $260 \mathrm{~kg} / \mathrm{m}^{3}$ have low thermal conductivity and water absorption, and high compressive strength and operating temperature.

The developed technology provides theopportunity to produce granulated foam glass ceramic products of various geometric shapes - plates, blocks, segments, shells and enables them to be recommended as an effective heat-insulating material not only in construction but also in thermal engineering $[10,11]$.

\section{Acknowledgement}

Parts of this work had financial support by Tomsk State University Competitiveness Improvement Program and Siberian Branch Program \#III.23.2.3.

\section{References}

[1] Schill, F.: Foam glass - Production and use; (translated to Russian from Check) 1965 Stroyizdat, Moscow (Russia) 307 p.

[2] Lang, G.: Common problems with the insulation on installations; Chemical processing, January 1984.
[3] Wen, G. - Zheng, X. - Song, L. - Huang, X. X.: Effects of $\mathrm{P}_{2} \mathrm{O}_{5}$ and sintering temperature on microstructure and mechanical properties of lithium disilicate glass-ceramics, 2009 Acta Materialia, V. 55, pp. 35833591 http://dx.doi.org/10.1016/j.actamat.2007.02.009

[4] Santos, F. A. - Fernandes, M. H. F. V. - Davim, E. - Pinatti, D. G. - Lazar, D. R. R. - Santos, C.: Crystalization of Biomaterial, the lithium disilicate, obtained from rice husk silica, 2013 IOP Conf. Ser.: Mater. Sci. Eng. 47 012003 http://dx.doi.org/10.1088/1757-899X/47/1/012003

[5] Hoffmann, L. - Józsa, Zs. - Nemes, R.: Glass Waste Lightweight aggregate for concrete from glass wastes "Geofil-Bubbles" - use options, (in Hungarian), Építőanyag, 2003, V.1, pp. 13-17. http://dx.doi.org/10.14382/epitoanyag-jsbcm.2003.3

[6] Mladenovič, A. - Šuput, J. S. - Ducman, V. - Škapin, A. S.: Alkali-silica reactivity of some frequently used lightweight aggregates, 2004, Cement and Concrete Research 34, 1809-1816 http://dx.doi.org/10.1016/j.cemconres.2004.01.017

[7] Bumanis, G. - Bajare, D. - Locs, J. - Korjakins, A.: Alkali-silica reactivity of expanded glass granules in structure of lightweight concrete, 2013 IOP Conf. Ser.: Mater. Sci. Eng. 47012022

http://dx.doi.org/10.1088/1757-899X/47/1/012022

[8] Demidovich, B.: Production and use of foam glass; Science and technology publishing, 1972 Minsk (Belorussia), $304 \mathrm{p}$

[9] Kudyakov, A.: Minerals of Tomsk region and their rational use of concrete technology; / TSU publishing, 1991 Tomsk (Russia), 222 p.

[10] Russian Federation invention patent № 2374191. "A method of producing of a granular foam glass ceramics" A. Apkarian, V. Khristyukov, reg. the $27^{\text {th }}$ of November 2009

[11] Apkaryan, A. S. - Khristyukov, V. G. - Smirnov, G. V.: Granulated foam glass ceramic - a promising heat insulating material. Glass and Ceramics, Springer New York Consultanks Bureau. 2008, T. 65 . № 3 - 4. pp. 74-76. http://dx.doi.org/10.1007/s10717-008-9018-1

Ref.:

Apkaryan, A. S. - Kulkov, S. N. - Gömze, L. A.: Foam Glass Ceramics as Composite Granulated Heat-Insulating Material Építöanyag - Journal of Silicate Based and Composite Materials, Vol. 66, No. 2 (2014), 38-42. p. http://dx.doi.org/10.14382/epitoanyag-jsbcm.2014.8

Habosított üveg-kerámia granulátumok, mint hőszigetelő kompozit anyagok

A pórusképzés fizikai és fizikokémiai folyamatának vizsgálataira támaszkodva a szerzốk gyártási technológiát dolgoztak ki habosított üveg-kerámia hôszigetelố granulátumok elôállítására ôrölt üvegcserép, agyag valamint szerves adalékanyag keverékébốl. A kutatások eredményeként meghatározásra kerültek az üveg habosodását befolyásoló tényezốk. Meghatározásra került az a rakat-összetétel intervallum, amelynél biztosított, hogy a pórusszerkezetet létrehozó, termikus bomlás során keletkezô szintézisgáz parciális nyomása kisebb legyen az ôt burokként körbevevõ megolvadt anyag felületi feszültségénél. Ennek köszönhetôen a duzzasztás - habosítás - során üvegesedett felületú zártpórusok sokaságát tartalmazó, megfelelô nyomószilárdsággal bíró anyagszerkezet jön létre, alacsony térfogat súrúséggel és vízfelvétellel. A duzzasztott üveg-kerámia szemcsék sưrúségét, hôvezetési tényezôjét, vízfelvételét és nyomószilárdságát a szerzôk a nyersanyag-összetétel és az égetési hômérséklet változtatásával szabályozták. A hôszigetelô adalékanyagként történô hasznosithatóság szempontjából legígéretesebbnek a $260-280 \mathrm{~kg} / \mathrm{m}^{3}$ térfogat-súrūségú, 1,74 MPa szemcseszilárdságú, 0,075 W/m ${ }^{\circ} \mathrm{C}$ hôvezetési tényezôvel rendelkezô és max. 2,6\% vízfelvételú hab-granulátumokat eredményezó keverék-összetétel és égetési technológia bizonyult.

Kulcsszavak: szén, agyag, ôrölt üveg, súrūség, tartósság, granulátum, üveg-kerámia, hôszigetelés, fúrészpor, hôvezetési tényezô, vízfelvétel 